\title{
Artemin Overexpression in Skin Enhances Expression of TRPV1 and TRPA1 in Cutaneous Sensory Neurons and Leads to Behavioral Sensitivity to Heat and Cold
}

\author{
Christopher M. Elitt, ${ }^{2 \star}$ Sabrina L. McIlwrath, ${ }^{1 \star}$ Jeffery J. Lawson, ${ }^{1}$ Sacha A. Malin, ${ }^{2}$ Derek C. Molliver, ${ }^{2}$ \\ Pamela K. Cornuet, ${ }^{2}$ H. Richard Koerber, ${ }^{1}$ Brian M. Davis, ${ }^{1,2}$ and Kathryn M. Albers ${ }^{1,2}$ \\ Departments of ${ }^{1}$ Neurobiology and ${ }^{2}$ Medicine, University of Pittsburgh School of Medicine, Pittsburgh, Pennsylvania 15261
}

\begin{abstract}
Artemin, a neuronal survival factor in the glial cell line-derived neurotrophic factor family, binds the glycosylphosphatidylinositolanchored protein GFR $\alpha 3$ and the receptor tyrosine kinase Ret. Expression of the GFR $\alpha 3$ receptor is primarily restricted to the peripheral nervous system and is found in a subpopulation of nociceptive sensory neurons of the dorsal root ganglia (DRGs) that coexpress the Ret and TrkA receptor tyrosine kinases and the thermosensitive channel TRPV1. To determine how artemin affects sensory neuron properties, transgenic mice that overexpress artemin in skin keratinocytes (ART-OE mice) were analyzed. Expression of artemin caused a 20.5\% increase in DRG neuron number and increased the level of mRNA encoding GFR $\alpha 3$, TrkA, TRPV1, and the putative noxious colddetecting channel TRPA1. Nearly all GFR $\alpha 3$-positive neurons expressed TRPV1 immunoreactivity, and most of these neurons were also positive for TRPA1. Interestingly, acid-sensing ion channel (ASIC) 1, 2a, 2b, and 3 mRNAs were decreased in the DRG, and this reduction was strongest in females. Analysis of sensory neuron physiological properties using an ex vivo preparation showed that cutaneous $\mathrm{C}$-fiber nociceptors of ART-OE mice had reduced heat thresholds and increased firing rates in response to a heat ramp. No change in mechanical threshold was detected. Behavioral testing of ART-OE mice showed that they had increased sensitivity to both heat and noxious cold. These results indicate that the level of artemin in the skin modulates gene expression and response properties of afferents that project to the skin and that these changes lead to behavioral sensitivity to both hot and cold stimuli.
\end{abstract}

Key words: sensory neuron; skin; pain; thermal sensitivity; gene expression; DRG

\section{Introduction}

Glial cell line-derived neurotrophic factor (GDNF) proteins (artemin, neurturin, and persephin) provide support for developing sensory, sympathetic, parasympathetic, and enteric neurons (Baloh et al., 2000; Enomoto et al., 2000; Airaksinen and Saarma, 2002). GDNF family ligands (GFLs) activate the Ret receptor tyrosine kinase through binding of glycosylphosphatidylinositolanchored GDNF family receptor $\alpha$ coreceptors (GFR $\alpha 1-4)$ (Sariola and Saarma, 2003). GDNF binds GFR $\alpha 1$, neurturin binds GFR $\alpha 2$, artemin binds GFR $\alpha 3$, and persephin binds GFR $\alpha 4$ (Lindahl et al., 2000; Carmillo et al., 2005). For cutaneous sensory neurons, GDNF supports development of small neurons with nociceptive properties. These neurons express GFR $\alpha 1$, are peptide poor, bind the lectin isolectin B4 (IB4), and some appear to be mechanonociceptors (Silverman and Kruger, 1988; Molliver

\footnotetext{
Received March 17, 2006; revised June 23, 2006; accepted June 24, 2006.

This work was supported by National Institute of Neurological Disorders and Stroke Grants NS33730, NS31826, and NS23725, and the National Institute of Diabetes and Digestive and Kidney Diseases Grant DK063922 (C.M.E., S.A.M.). We thank Beth Knapick and Christopher Sullivan for technical assistance and D. Corey (Harvard University, Boston, MA) for generously providing the TRPA1 antibody.

${ }^{*}$ C.M.E. and S.L.M. contributed equally to this work.

Correspondence should be addressed to Dr. Kathryn M. Albers, Department of Medicine, University of Pittsburgh Scaife Hall, Room S857, Pittsburgh, PA 15261. E-mail: kaa2@pitt.edu.

DOI:10.1523/JNEUROSCI.2185-06.2006

Copyright $\odot 2006$ Society for Neuroscience $\quad$ 0270-6474/06/268578-10\$15.00/0
}

et al., 1997; Bennett et al., 1998; Albers et al., 2006). The role of neurturin-responsive, GFR $\alpha 2$-positive neurons is less clear. Mice lacking neurturin have fewer GFR $\alpha 2$-positive neurons and defects in innervation to the skin, enteric nervous system, and glands (Heuckeroth et al., 1999; Lindfors et al., 2006). IB4positive neurons from GFR $\alpha 2^{-/-}$mice exhibit reduced heat currents, suggesting neurturin modulates thermal responsiveness (Stucky et al., 2002).

Less is known about artemin and its affects on sensory neurons. Artemin is expressed by smooth muscle of the vasculature (Honma et al., 2002), hippocampal neurons (Quartu et al., 2005), carotid body cells (Leitner et al., 2005), gut tissues (Lucini et al., 2005), and skin (this report). Artemin-responsive, GFR $\alpha 3$ positive sensory neurons are small and comprise $\sim 20 \%$ of the mouse L5 dorsal root ganglia (DRGs) (Naveilhan et al., 1998; Orozco et al., 2001). GFR $\alpha 3$ neurons are particularly interesting because $80 \%$ of these neurons coexpress Ret and TrkA and are therefore responsive to artemin and nerve growth factor (NGF). In addition, $99 \%$ of these neurons express the thermosensitive transient receptor potential (TRP) channel TRPV1. TRPV1positive neurons contribute to nociceptive signaling because mice that lack TRPV1 have attenuated responses to noxious heat after inflammation (Caterina et al., 2000; Davis et al., 2000). In heterologous systems, TRPV1 and the related receptor TRPV2 are activated by high temperatures $\left(>42^{\circ} \mathrm{C}\right)$, whereas TRPV 3 and 
TRPV4 are activated by lower temperatures $\left(30-35^{\circ} \mathrm{C}\right)$. In mice, TRPV1 is mainly expressed in IB4-negative, peptidergic neurons (Zwick et al., 2002). Some sensory neurons also express the coldactivated TRP channels, TRP (melastratin)-8 (TRPM8) and TRP (ankyrin-like)-1 (TRPA1) (McKemy et al., 2002; Story et al., 2003; Reid, 2005). TRPM8 is activated by cool stimuli ( $<23-$ $28^{\circ} \mathrm{C}$ ) and menthol, whereas TRPA1 responds to colder temperatures $\left(<18^{\circ} \mathrm{C}\right)$, responds to natural compounds such as mustard and cinnamon oils (Story et al., 2003; Bandell et al., 2004), and has a role in auditory hair cells (Corey et al., 2004).

To better understand the function of artemin-responsive neurons, we isolated transgenic mice that overexpress artemin in the skin. The effect of artemin on developmental survival of cutaneous sensory neurons, TRP and acid-sensing ion channel (ASIC) gene expression, cutaneous afferent anatomy, physiology, and thermoresponsive behavior were examined. Our findings indicate that neurons responsive to artemin have unique physiological properties and that artemin significantly modulates expression of temperature-sensitive channels and behavioral thermal sensitivity.

\section{Materials and Methods}

Generation of transgenic mice. Mice were generated and screened as described previously for other growth factor genes (Albers et al., 1994, 1996; Zwick et al., 2002). A 1100 bp fragment was PCR cloned from genomic DNA isolated from mouse liver using primers (5'-CGAAAGCTATGGAACTGGGA-3'; 5'-GATCATCCTCAGCCCAGACA-3') that encompass nucleotides of the artemin gene (GenBank accession number NT039264) (Honma et al., 2002). The amplified fragment, which contains two intronic sequences within the artemin coding region (see Fig. $1 A$ ), was cloned into the pCR4-TOPO vector (Invitrogen, San Jose, CA), and its sequence fidelity was verified by DNA sequencing in the University of Pittsburgh Genomics and Proteomics Core Laboratory. A purified fragment containing $2.3 \mathrm{~kb}$ of the human K14 keratin promoter sequence, $1.1 \mathrm{~kb}$ of mouse artemin DNA, and $1.7 \mathrm{~kb}$ of the human growth hormone gene containing intron/exon and poly(A) signal sequences was injected into C57Bl6J/C3H F1 hybrid fertilized oocytes. Founder lines were screened using slot-blot assays performed on DNA from tail skin using transgene- and artemin-specific random primed ${ }^{32} \mathrm{P}-\mathrm{dCTP}$ labeled probes. Reverse transcriptase-PCR (RT-PCR) analysis of RNA from founder offspring backskin was used to assay the relative level of transgene expression. Detailed analysis was focused on the transgenic line that exhibited the highest transgene copy number. Primers to detect endogenous and transgenic artemin (5'-CTCAGTCTCCTC AGCCCG- $3^{\prime}$ and 5' $^{\prime}$-TCCACGGTCCTCCAGGTG-3') as well as transgene-specific primers (5'-CGAGCTGATACGTTTCCCGCTTC-3' and $5^{\prime}$-AAGAGGGCAGCCAGTGTTTCTC-3') were used. Analyses were performed on male and female transgenic and wild-type (WT) mice between 4 and 8 months old that were kept under Association for Assessment and Accreditation of Laboratory Animal Care conditions in the animal facility of the University of Pittsburgh. Animals were cared for and used in accordance with guidelines of the United States Public Health Service Policy on Humane Care and Use of Laboratory Animals and the National Institutes of Health Guide for the Care and Use of Laboratory Animals.

RT-PCR analysis. RNA was extracted from trigeminal and pooled lumbar (L3/L4/L5) DRGs from deeply anesthetized mice perfused transcardially with ice-cold phosphate buffer. RNA was isolated using Trizol reagent (Invitrogen) after an isopropanol precipitation and a 70\% ethanol wash. RNA suspended in RNase-free water was DNase treated and 1 $\mu \mathrm{g}$ was reverse transcribed using Superscript II (Invitrogen). Routine control reactions included PCRs on DNased RNA (without RT) and reactions run without templates to test for contamination. SYBR Greenlabeled PCR amplification was performed using a real-time thermal cycler (Applied Biosystems, Foster City, CA) controlled by a Dell Latitude laptop computer running Prism 7000 SDS software (Applied Biosystems). Reactions and analyses were performed as described by Molliver et
Table 1. Primer sequences used for real-time PCR assays

\begin{tabular}{lll}
\hline Gene & Forward primer $\left(5^{\prime} \rightarrow 3^{\prime}\right)$ & Reverse primer $\left(5^{\prime} \rightarrow 3^{\prime}\right)$ \\
\hline GFR $\alpha 3$ & CTTGGTGACTACGAGTTGGATGTC & AGATTCATTTTCCAGGGTTGC \\
C-RET & ACTCGGCTCTGAGATAGACA & AGACCTTGTCCAGGTCACAA \\
TrkA & AGAGTGGCTCCGCTTGG & CGCATTGGAGGACAGATTCA \\
TRPV1 & TTCCTGCAGAAGAGCAAGAAGC & CCCATTGTGCAGATTGAGCAT \\
TRPV2 & CCAGCCATTCCCTCATCAAAA & AAGTACCACAGCTGGCCCAGTA \\
TRPV3 & TGAAAGAAGCATTGCCATTT & GAAACCAGGCATCTGACAGGAT \\
TRPV4 & TGGATTCCTTGTTCACTACGG & CACAATGTCAAAGAGATGGGC \\
TRPA1 & GCAGGTGGACTTCATACCAACT & CACTTTGCGTAAGTACCAGAGTGG \\
ASIC1 & CTGGACTTCCTAGTGGAGAA & CCAGCACCAGAATATTCTCC \\
ASIC2 $a$ & ATGGACCTCAAGGAGAGCCCCAG & AAGTCTTGATGCCCACACTCCTGC \\
ASIC2b & CGCACAACTTCTCCTCAGTGTTAC & TTGGATGAAAGGTGCTCAGAC \\
ASIC3 & ATGAACCTCCCTCAGGACTGG & AACTCCCATAGTAGCGACCC \\
GAPDH & ATGTGTCGTCGTGGATCTGA & ATGCCTGCTTCACCACCTTCTT \\
\hline
\end{tabular}

al. (2005) using primers designed using Applied Biosystems software (Table 1). RT-PCR analysis on skin samples and for ASIC assays were performed by running ${ }^{32} \mathrm{P}$-dCTP spiked PCRs on $8 \%$ polyacrylamide gels and calculating the relative amount of PCR product using a BioRad (Richmond, CA) phosphorimager. SYBR Green- and ${ }^{32} \mathrm{P}$-dCTP labeled reactions were normalized to glyceraldehyde-3-phosphate dehydrogenase (GAPDH) levels, which were unchanged in transgenic tissues.

Tissue immunolabeling. Skin, ganglia, and spinal cord collected from animals perfused with saline were placed in $30 \%$ sucrose, embedded in OCT compound, and cut on a cryostat at $20 \mu \mathrm{m}$ thickness. Sections were fixed either for $10 \mathrm{~min}$ in $-20^{\circ} \mathrm{C}$ acetone (GFR $\alpha 3$ and TRPA1 labeling) or for $10 \mathrm{~min}$ in $4^{\circ} \mathrm{C} 4 \%$ paraformaldehyde [TRPV1, calcitonin generelated peptide (CGRP), and IB4]. The percentage of neurons labeled was determined by comparing the number of GFR $\alpha 3$-positive, TRPV1positive, or both TRPV1- and GFR $\alpha 3$-positive neurons with the total number of neurons labeled with antibodies to peripherin and neurofilament 200, which represents nearly all neurons in the ganglia. At least three $40 \times$ fields from a minimum of four nonadjacent sections were counted. Only neurons with visible nuclei were counted to avoid counting errors that could result from artemin-overexpresser (ART-OE) neuron hypertrophy. A minimum of 1000 neurons per animal was counted in at least three WT and three ART-OE mice. Somal size was measured using NIH ImageJ software using at least 150 profiles with nuclei per animal. The antibodies used were rabbit anti-artemin $(5 \mu \mathrm{g} / \mathrm{ml}$; R \& D Systems, Minneapolis, MN), anti-TRPV1 (1:250 skin, 1:500 ganglia; Oncogene Research, San Diego, CA), goat anti-GFR $\alpha 3$ (1:80; R \& D Systems), mouse anti-peripherin (1:400; Chemicon, Temecula, CA), mouse anti-neurofilament 200 (1:400; Sigma, St. Louis, MO), rabbit anti-CGRP (1:1000; Sigma), and rabbit anti-TRPA1 $(10 \mu \mathrm{g} / \mathrm{ml}$; a generous gift from D. Corey, Harvard University, Boston, MA) (Corey et al., 2004). IB4 conjugated to $\mathrm{Cy} 3$ was purchased from Invitrogen and used at 1:200. Donkey anti-rabbit and donkey anti-goat secondary antibodies (Jackson ImmunoResearch, West Grove, PA) were used at 1:200. Images of immunolabeled sections were captured using a confocal microscope (Leica, Wetzlar, Germany).

Neuron cell counts. The number of L4 DRG neurons was estimated using previously described methodology (Harrison et al., 2004). WT $(n=4)$ and ART-OE $(n=3)$ mice were deeply anesthetized, they were perfused with $0.9 \% \mathrm{NaCl}$, and their $\mathrm{L} 4$ ganglia were collected. Ganglia were postfixed in $4 \%$ paraformaldehyde for $30 \mathrm{~min}$. Serial $8 \mu \mathrm{M}$ sections stained with cresyl violet were analyzed by counting neurons with visible nucleoli from at least 10 equally spaced sections. Final estimates of cell number were obtained from raw counts that were adjusted using a correction factor to account for neurons with multiple nucleoli that theoretically could be counted more than once.

Electrophysiology. An ex vivo somatosensory preparation in which the skin, nerve, DRGs, and spinal cord are intact was used (Koerber and Woodbury, 2002). Adult mice (3-6 months old) were anesthetized with an intramuscular injection of a mix of ketamine $(90 \mathrm{mg} / \mathrm{kg})$ and xylazine $(10 \mathrm{mg} / \mathrm{kg})$. Animals were perfused transcardially through the left ventricle with chilled $\left(14^{\circ} \mathrm{C}\right)$ and oxygenated $\left(95 \% \mathrm{O}_{2} / 5 \% \mathrm{CO}_{2}\right)$ artificial 
CSF (aCSF) in which most sodium cations had been replaced with sucrose (in mM: 253.9 sucrose, $1.9 \mathrm{KCl}, 1.2 \mathrm{KH}_{2} \mathrm{PO}_{4}, 1.3 \mathrm{MgSO}_{4}, 2.4 \mathrm{CaCl}_{2}$, $26.0 \mathrm{NaHCO}_{3}, 10.0 \mathrm{D}$-glucose). The spinal cord and the right hindlimb were excised and placed in a circulating bath of the same solution. In this circulating bath, the spinal cord, DRGs, saphenous nerve, and the skin innervated by this nerve were isolated. The isolated preparation was transferred to a recording chamber containing oxygenated aCSF in which sodium ions had been replaced and the skin was pinned out on a mesh-covered platform. The level of the bath was lowered so that the epidermis was at the surface and allowed to dry. Somata in L2 and L3 DRGs were impaled using quartz microelectrodes (Vector Laboratories, Burlingame, CA). The peripheral response properties of the cell were assessed using controlled thermal and mechanical stimuli, and the mechanical responses of the cell were quantified using a feedback controlled constant force stimulator (Aurora Scientific, Aurora, Ontario, Canada). Stimuli included a series of single $5 \mathrm{~s}$ square waves of varied forces $(1,5$, $10,25,50$, and $100 \mathrm{mN}$ ) using a 1 -mm-diameter probe. After mechanical stimulation, the response of the cell to thermal stimulation was determined using a contact peltier stimulator (Yale University, New Haven, $\mathrm{CT}$ ). The receptive field was slowly heated $(15 \mathrm{~s})$ from 31 to $52^{\circ} \mathrm{C}$ and held for $5 \mathrm{~s}$ before returning to bath temperature.

Calcium imaging. DRG neurons were grown using procedures described by Molliver et al. (2002). DRGs from all spinal cord levels were incubated in $60 \mathrm{U}$ of papain in a solution of cysteine $(1 \mathrm{mg} / 3 \mathrm{ml}$ HBSS $)$ and saturated $\mathrm{NaHCO}_{3}$ for $10 \mathrm{~min}$ at $37^{\circ} \mathrm{C}$. The solution was then removed, and $12 \mathrm{mg}$ of collagenase type II in $3 \mathrm{ml}$ of HBSS was added for 10 $\min$ at $37^{\circ} \mathrm{C}$. Next, collagenase was removed, and cells were washed in F-12 medium (Invitrogen) containing 10\% fetal bovine serum (FBS). The mixture was then gently triturated and plated onto laminin $(0.1$ $\mathrm{mg} / \mathrm{ml}$ )-coated and poly-D-lysine $(5 \mathrm{mg})$-coated glass coverslips. Cells were incubated for $2 \mathrm{~h}$ at $37^{\circ} \mathrm{C}$, fed F-12 medium with $10 \% \mathrm{FBS}$, and incubated overnight. Cells were loaded with calcium indicator by incubation with HBSS containing bovine serum albumin and $2 \mu \mathrm{M}$ of the acetoxymethyl ester of fura-2 (Invitrogen) for $30 \mathrm{~min}$ at $37^{\circ} \mathrm{C}$. Coverslips were placed on a Leica microscope stage mount with a $30^{\circ} \mathrm{C}$ HBSS buffer flowing at $5 \mathrm{ml} / \mathrm{min}$, and firmly attached, refractile cells were chosen and identified as regions of interest in the software (Simple PCI; C-Imaging, Compix Imaging Systems, Sewickley, PA). Absorbance data at 340 and $380 \mathrm{~nm}$ were collected at $1 / \mathrm{s}$, and the relative fluorescence ( $340 / 380$ ratio) was analyzed. Calcium transients were examined in response to brief (1-2 s) local application of either $1 \mu \mathrm{M}$ capsaicin or $100 \mu \mathrm{M}$ ATP using a rapid-switching perfusion system (Warner Instruments, Hamden, CT). Response parameters were compared for significance using Student's $t$ test.

Behavioral analysis. Eight WT and eight ART-OE transgenic mice of mixed gender were tested for heat sensitivity using the Hargreaves' test (Hargreaves et al., 1988). Mice were placed on a $30^{\circ} \mathrm{C}$ heated glass surface in individual chambers $(10.0 \times 10.0 \times 13.0 \mathrm{~cm})$ of a 16 -chamber Plexiglas container (IITC, Woodland Hills, CA). Animals were acclimated to the apparatus for $1.5 \mathrm{~h}$ before testing. The apparatus was set at a laser intensity of $15 \%$, and testing was performed using repeated measures (three measures per foot) of the left and right glabrous hindpaw skin. Six response times were averaged for each animal. Mean response times for each set of animals were determined, and values \pm SEM were expressed. Significance was determined using Student's $t$ test ( $n=8$ per group). For cold measures, individual mice (10 WT, 10 ART-OE) were restrained in an open-ended tube and the distal third of the tail was immersed in an ethanol bath (Mogil and Adhikari, 1999). Assays were performed at 0 and $-15^{\circ} \mathrm{C}$ on two different sets of mice. The time until a vigorous tail withdrawal response occurred was measured to $0.1 \mathrm{~s}$ using a stopwatch.

\section{Results}

\section{Artemin overexpression in skin enhances neuron number in sensory ganglia}

The human K14 keratin promoter directed expression of artemin in basal keratinocytes of the epidermis and keratinized epithelium of the oral cavity (Fig. 1A). K14-driven transgene expression begins at approximately embryonic day 11 (E11) in whisker pad
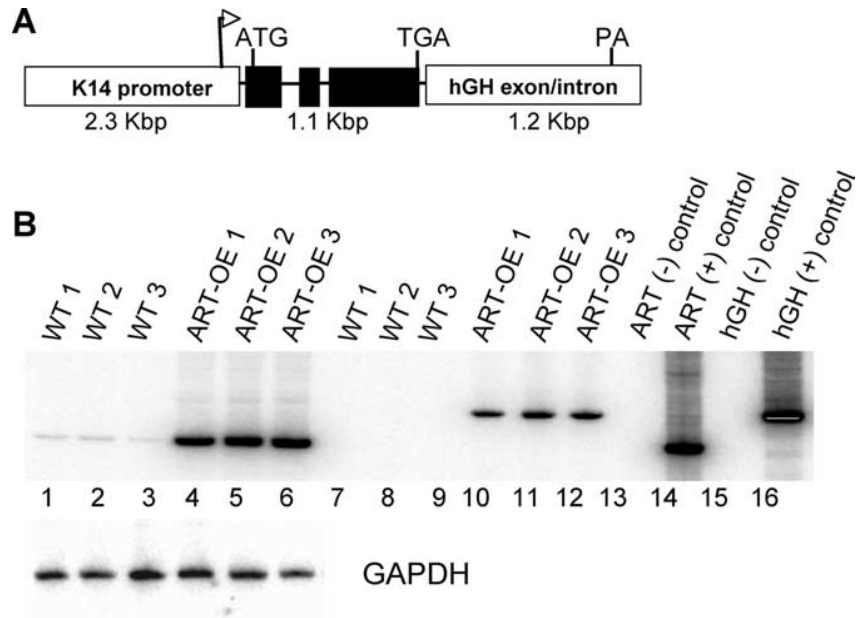

Figure 1. Overexpression of artemin in the skin is driven by the K14 keratin promoter. $A$, Diagram of transgene construct used for isolation of ART-OE mice. The K14 promoter drives expression of the artemin sequence represented by black boxes. Lines connecting the boxes indicate two intronic sequences retained in the artemin sequence. The 3 ' human growth hormone sequence provides splice sites and a poly $(A)$ addition signal. The arrow indicates the transcription start site, and ATG and TGA are translation start and stop sites, respectively. $\boldsymbol{B}$, RT-PCR analysis of RNA isolated from WT $(n=3)$ and transgenic (ART-OE; $n=3$ ) back skin showing increased expression of artemin mRNA in ART-0E skin. Lanes 1-6, Amplicons obtained using primers to the artemin gene sequence; lanes $7-12$, products using transgene-specific $P C R$ primers; lanes 13 and 15 , negative controls for the $P C R$; lanes 14 and 16 , positive controls for the artemin and transgene sequences, respectively. Note significant enhancement in the level of artemin mRNA and lack of transgene expression in transgenic skin samples. hGH, Human growth hormone; $P A$, poly(A).

skin, continues into adulthood (Figueiredo et al., 2001), and has been shown to successfully express high levels of NGF, NT3, BDNF, NT4, and GDNF in the skin and oral cavity (Albers et al., 1994, 1996; Krimm et al., 2001; Zwick et al., 2002). RT-PCR analysis of transgene expression showed a low level of artemin mRNA in skin from WT mice and an enhanced level in skin of ART-OE mice (Fig. $1 B$ ). On the protein level, comparison of artemin immunolabeling of WT and ART-OE skin showed only slight reactivity in the WT epidermis and a significant enhancement in artemin immunoreactivity in transgenic skin that was restricted to the K14 keratin-expressing keratinocytes (Fig. 2A). This increase in artemin resulted in trigeminal ganglia and DRGs from ART-OE mice that were visibly enlarged in size (Fig. 2 B). Counts of the number of neurons in the L4 DRGs of three WT and three ART-OE animals showed this enlargement was attributable, at least in part, to a $20.5 \%$ increase in neuron number (WT, $4800 \pm 119$; ART-OE, $5788 \pm 250 ; p<0.011$ ), supporting a role for artemin as a developmental survival factor for a subpopulation of sensory neurons. In this role, retrograde transport of artemin from the skin would be expected. We therefore labeled WT and ART-OE ganglia using an anti-artemin antibody, which showed artemin-positive neurons only in the ART-OE ganglia (Fig. 2C). To assess central changes, the density of peptidergic (CGRP positive) and nonpeptidergic (IB4) afferent innervation to the spinal cord dorsal horn was determined (Fig. 2D). No significant difference in either projection was observed.

\section{Artemin overexpression modulates expression of GFR $\alpha 3$ receptor}

Artemin activates src-family kinase-dependent cell-signaling pathways after binding to its GFR $\alpha 3$ and Ret kinase receptor complex (Encinas et al., 2001; Carmillo et al., 2005). Sensory 

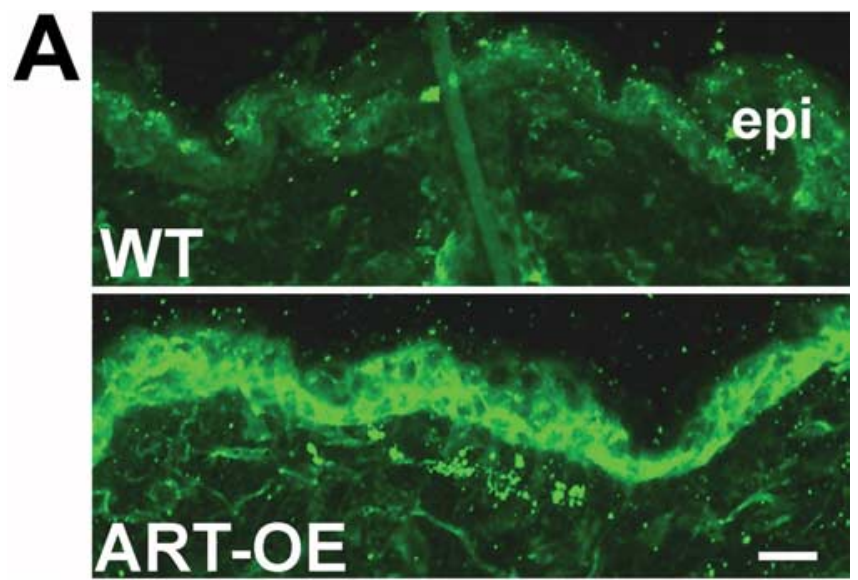

B
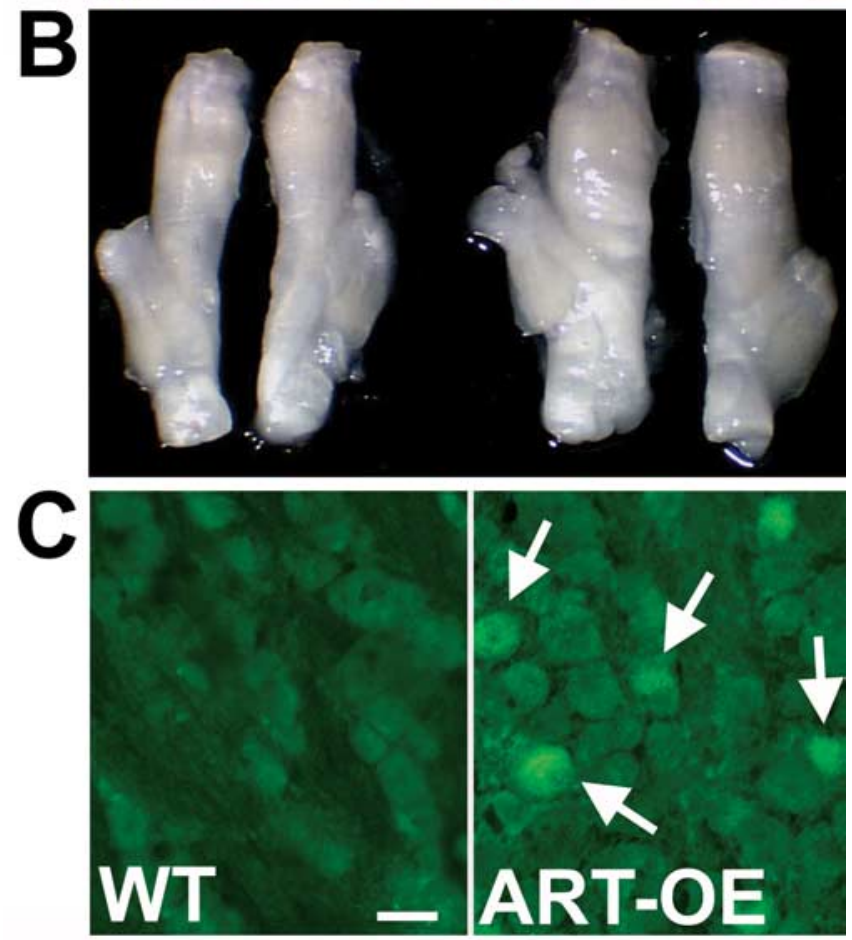

D

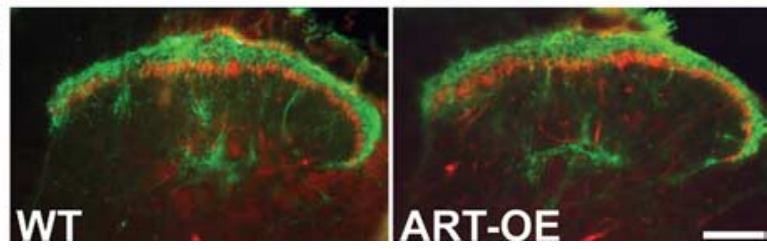

Figure 2. Skin-expressed artemin increases the number of sensory neurons and is retrogradely transported to the ganglia. $\boldsymbol{A}$, Immunolabeling of whisker pad skin from WT (top) and ART-0E (bottom) mice using an antibody to artemin. Artemin protein is significantly increased in basal keratinocytes of ART-OE mice. Scale bar, $25 \mu \mathrm{m}$. epi, Epidermis. $\boldsymbol{B}$, Left, Set of trigeminal ganglia from littermate WT mouse. Right, Ganglia from ART-0E mice are larger relative to WT ganglia. DRGs showed a similar enlargement (not shown). $C$, Artemin is retrogradely transported from the skin as indicated by artemin immunoreactivity in trigeminal ganglia neurons of ART-OE (arrows) but not WT mice. Scale bar, $35 \mu \mathrm{m}$. D, Spinal cord dorsal horn of WT and ART-0E mice labeled with anti-CGRP (green) and IB4 (red). No significant difference was observed in the distribution or density of CGRP peptidergic or IB4 nonpeptidergic afferents. Scale bar, $100 \mu \mathrm{m}$.

ganglia were therefore labeled using an anti-GFR $\alpha 3$ antibody to determine whether the properties of GFR $\alpha 3$-positive neurons changed in response to the increase in skin-derived artemin (Fig. 3). The percentage of GFR $\alpha 3$-positive neurons was unchanged in
ART-OE ganglia (WT, $19.64 \pm 0.57 \%$; ART-OE, $18.07 \pm 1.47$ ), and cell diameter measures showed these neurons to be hypertrophied (WT, $20.03 \pm 0.67 \mu \mathrm{m}$; ART-OE, $26.09 \pm 0.99 \mu \mathrm{m} ; p<$ 0.05 ) (Fig. $3 A, D)$. GFR $\alpha 3$ expression was also examined on the transcriptional level by assaying the relative abundance of GFR $\alpha 3$ mRNA in WT and ART-OE ganglia (Table 2). Real-time PCR analysis of lumbar DRG RNA showed GFR $\alpha 3$ mRNA increased by $34 \%$ in ganglia of ART-OE animals ( $p \leq 0.002$ ). Because the percentage of GFR $\alpha 3$-positive neurons was unchanged, this increase in GFR $\alpha 3$ mRNA suggests its expression was elevated on a per-cell level. Interestingly, transcripts encoding tyrosine kinases Ret and TrkA, which are coexpressed in $\sim 80 \%$ of GFR $\alpha 3$ positive neurons (Orozco et al., 2001), were differentially regulated in ART-OE ganglia (Table 2). Relative to WT ganglia, the Ret transcript level was unchanged, whereas TrkA mRNA levels were increased 37\% ( $p \leq 0.005)$ in parallel with the 34\% elevation in GFR $\alpha 3$ (Table 2).

Artemin overexpression in the skin increases the level of TRPV1 mRNA but decreases expression of ASIC mRNAs in a sex-specific manner

Virtually all artemin-responsive (GFR $\alpha 3$-positive) sensory neurons express the capsaicin receptor TRPV1 (Orozco et al., 2001). We therefore tested whether transcriptional regulation of TRPV1 or other TRPV channel genes was altered in ART-OE ganglia using RT-PCR analysis of RNA isolated from pooled lumbar (L3/ L4/L5) ganglia (Table 2). Compared with WT, the TRPV1 transcript level was $61 \%$ higher in ART-OE DRGs $(p \leq 0.0005)$. No change in the TRPV2, TRPV3, or TRPV4 mRNA level was measured.

The relative expression of genes encoding members of the ASIC family was also measured (Table 3). ASICs are protongated sodium channels that are proposed to underlie acid-evoked pain and at least some aspects of mechanical sensation (Price et al., 2001; Benson et al., 2002; Krishtal, 2003; Jones et al., 2005; Albers et al., 2006). The relative expression of ASIC1, ASIC2a, ASIC2b, and ASIC3 was determined using RT-PCR assays of pooled lumbar ganglia. Interestingly, a significant decrease in all subtypes occurred in ganglia from female mice (ASIC1, 44.3\%; ASIC2, 72.7\%; ASIC2b, 44.4\%; ASIC3, 61.2\%). These were in contrast to male ganglia, in which only ASIC2a was decreased (48.6\%). This sex-specific difference was not observed for other genes assayed (receptors, TRP channels, and GAPDH).

Artemin causes hypertrophy of TRPV1-positive afferents Immunolabeling of L4/L5 DRG with antibodies to TRPV1 and GFR $\alpha 3$ (Fig. 3) showed most GFR $\alpha 3$-positive neurons expressed TRPV1 in both WT $(94.25 \pm 0.88 \%)$ and ART-OE $(96.55 \pm 2.00)$ mice, although not all TRPV1 neurons were GFR $\alpha 3$ positive (in either WT or ART-OE). The overall percentage of TRPV1 neurons in ART-OE mice was also unchanged compared with WT mice (WT, $27.53 \pm 1.19 \%$ vs ART-OE, $28.81 \pm 2.75 \%$ ). Similar to the GFR $\alpha 3$ population, the total number of TRPV1-positive neurons must have increased because of the increase in overall neuron number. TRPV1 neurons in ART-OE ganglia also showed hypertrophy in size (WT, $20.42 \pm 3.90 \%$ vs ART-OE, $24.43 \pm 1.39 \% ; p<0.05$ ) (Figs. $2 B, 3 A$ ), confirming that the GFR $\alpha 3 /$ TRPV1 neuron population was responsive to artemin.

The increased diameter of TRPV1-positive neurons raised the possibility that enhanced levels of artemin alter peripheral projection patterns of TRPV1-positive neurons. Therefore, skin innervation was examined by immunolabeling whisker pad, backskin, and footpad skin. Using the general neuronal marker 
PGP-9.5, no major change in innervation density or projection pattern was found in these regions (data not shown). Colabeling of WT and ART-OE whisker pad and footpad skin using anti-GFR $\alpha 3$ and antiTRPV1 antibodies, however, did reveal a significant change in afferent innervation in ART-OE skin. Whisker pad (Figs. 4, 5) and footpad skin (data not shown) of ART-OE mice showed greater density of GFR $\alpha 3$-labeled afferents compared with WT skin (Fig. 4, compare $A, D$; compare Fig. $5 A, D)$. In addition, the number of TRPV1-positive afferents in ART-OE skin was significantly increased in dermal and epidermal compartments (Fig. 4, compare $B, E$; Fig. 5, compare $B, E$ ). Thus, increased artemin in skin enhances projections of TRPV1- and GFR $\alpha 3$-positive fibers. Whether this is attributable to an increase in the number of TRPV1/GFR $\alpha 3$-positive afferents and increased branching of processes is unclear. However, the somal hypertrophy of these neurons and increase in TRPV 1 and GFR $\alpha 3$ mRNA expression is consistent with the presence and maintenance of more highly branched peripheral processes. Also of note was that the epidermis of ART-OE skin appeared thinner in some sections of skin (Fig. 5), suggesting that increased levels of artemin affects keratinocyte turnover.

\section{The TRPA1 channel protein is a marker for GFR $\alpha 3$ neurons} and is modulated by artemin level

In addition to TRPV1, increased skin expression of artemin led to enhanced expression of TRPA1, a channel protein reported to be activated by pungent compounds and noxious cold (Peier et al., 2002; Bandell et al., 2004; Bautista et al., 2005). TRPA1 mRNA was increased $210 \%$ in the DRGs of ART-OE transgenic mice compared with wild type (Table 2). In WT (Fig. 6A-C) and ART-OE (Fig. 6D-F) trigeminal ganglia and DRGs immunolabeled with antibodies to TRPA1 and GFR $\alpha 3$, a large degree of overlap in TRPA 1 and GFR $\alpha 3$ expression occurred. Based on this overlap, it appears that TRPA1 is expressed by nearly all sensory neurons that are GFR $\alpha 3$ positive and therefore artemin responsive and TRPV1 positive. In addition, TRPA1 immunolabeling of neurons in transgenic ganglia appeared more intense, likely reflecting the increase in TRPA1 mRNA shown by RT-PCR assay (Table 2). TRPM8 was also assayed in trigeminal ganglia and found to be unchanged, although a trend toward reduction $(-36 \%)$ of this transcript occurred in ART-OE ganglia $(p=$ 0.055 , two-tailed $t$ test).

\section{Artemin alters thermal but not mechanical response properties of cutaneous C-fibers}

Modulation of TRPV1 and TRPA1 ion channel expression by artemin suggests changes in cutaneous afferent receptive properties occur in ART-OE mice. To test this, a skin/saphenous nerve/ DRG/spinal cord ex vivo preparation was used to measure peripheral response properties of cutaneous sensory neurons in ART-OE mice (Ritter et al., 2000; Woodbury and Koerber, 2003). Identified afferents from eight ART-OE mice and seven agematched WT mice were examined for mechanical and thermal sensitivity (Fig. 7). Mechanical thresholds of C-fiber afferents
Table 2. Change in expression of receptor and TRP channel genes in lumbar DRGs (L3, L4, and L5) of WT and ART-0E mice

\begin{tabular}{ll}
\hline Gene assayed & Percentage change \\
\hline GFR $\alpha 3$ & $+34 \%^{*}$ \\
Ret & $+6 \%$ \\
TrkA & $+37 \%^{*}$ \\
TRPV1 & $+61 \%^{* *}$ \\
TRPV2 & $+6 \%$ \\
TRPV3 & $-28 \%$ \\
TRPV4 & $+8 \%$ \\
TRPA1 & $+210 \%^{* *}$ \\
\hline
\end{tabular}

RT-PCR assays using RNA from DRGs of individual animals were performed using four to six animals per group. ${ }^{* *} p \leq 0.0005 ;{ }^{*} p<0.005$

Table 3. Change in level of ASIC mRNAs in lumbar DRGs $(L 3, L 4$, and $L 5)$ of WT and ART-OE mice

\begin{tabular}{llll}
\hline & \multicolumn{3}{l}{ Percentage change } \\
\cline { 2 - 4 } Gene assayed & Males & Females & Males and females \\
\hline ASIC1 & $-2.62 \%$ & $-44.3 \%^{*}$ & $-47.4 \%$, n.s. $(p=0.06)$ \\
ASIC2a & $-48.6 \%^{*}$ & $-72.7 \%^{*}$ & $-46.9 \%^{* *}$ \\
ASIC2b & $-23.9 \%$ & $-44.4 \%^{*}$ & $-34.5 \%^{*}$ \\
ASIC3 & $-5.10 \%$ & $-61.2 \%^{*}$ & $-33.4 \%$, n.s. \\
\hline
\end{tabular}

RT-PCR assays using RNA from DRGs of individual animals were performed. The groups assayed were five WT males, four WT females, six ART-OE males, and four ART-0E females. ${ }^{*} p<0.05$; ${ }^{* *} p<0.01$. n.S., Not significant.

were unchanged (WT, $17.0 \pm 5.3 \mathrm{mN}$; ART-OE, $14.6 \pm 5.3 \mathrm{mN}$ ) as were mean firing rates after mechanical stimulation (Fig. $7 A$ ). In contrast, a significant change in thermal sensitivity of C-fiber afferents in ART-OE mice was detected (Fig. 7B). Both a decrease in heat threshold (WT: $40.8 \pm 1.1^{\circ} \mathrm{C}, n=19$; ART-OE: $36.8 \pm$ $\left.0.7^{\circ} \mathrm{C}, n=22 ; p<0.01\right)$ and an increase in sensitivity, measured as mean firing rate per degree Celsius (Fig. $7 B$ ), were exhibited in ART-OE preparations.

Sensory neurons of ART-OE mice are sensitized to capsaicin Expression of artemin increased TRPV $1 \mathrm{mRNA}$ and lowered heat threshold of C-fiber afferents, suggesting that artemin enhances TRPV1 channel responses in sensory neurons. To further exam- 

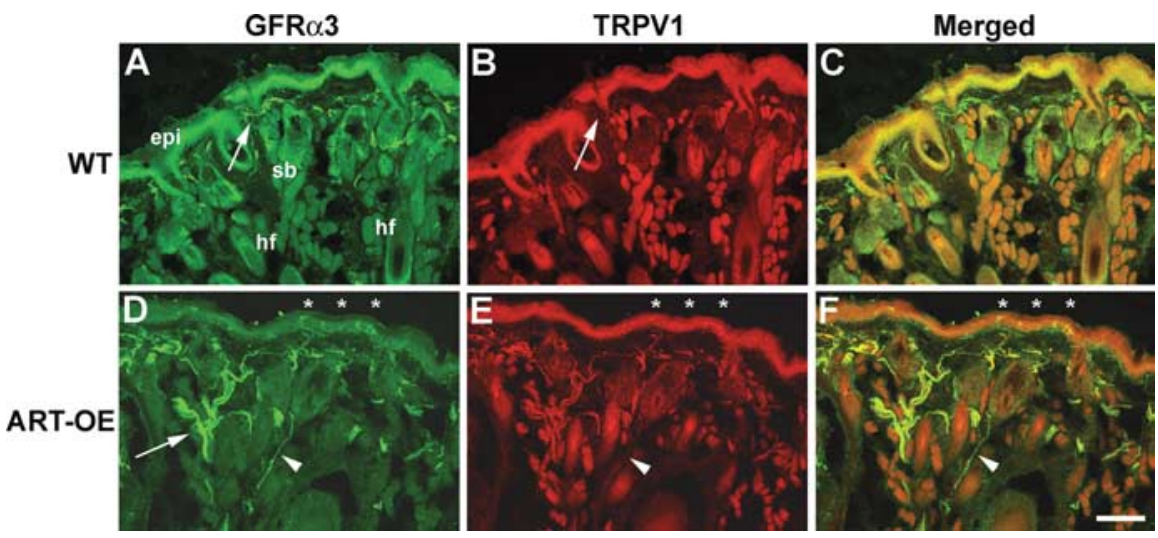

Figure 4. Skin-derived artemin increases cutaneous GFR $\alpha 3$-positive afferents and intensity of TRPV1 labeling. Low-power view compares innervation of whisker pad skin of WT $(\boldsymbol{A}-\boldsymbol{C})$ and ART-OE $(\boldsymbol{D}-\boldsymbol{F})$ animals. An increase in GFR $\alpha 3$-positive afferents (green, arrows) occurs in dermis of ART-0E skin. Immunolabeling with anti-TRPV1 (red; $\boldsymbol{B}, \boldsymbol{E}$ ) shows high expression in ART-0E afferents $(\boldsymbol{E})$. Few TRPV1 fibers were seen in WT skin $(\boldsymbol{B})$. TRPV1 labeling of GFR $\alpha 3$ afferents of ART-OE skin was particularly evident in merged images $(\boldsymbol{F})$ where overlap appears yellow. Overlap was rarely seen in WT skin $(\boldsymbol{C})$. Asterisks in $\boldsymbol{D}-\boldsymbol{F}$ indicate appearance of GFR $\alpha 3$ and TRPV1 afferents in epidermis of ART-0E skin (see Fig. 4). Arrowheads in $\boldsymbol{D}-\boldsymbol{F}$ indicate a GFR $\alpha 3$-positive fiber that is not TRPV1 positive and may represent sympathetic innervation. Scale bar (in $\boldsymbol{F}$ ), $100 \mu \mathrm{m}$. epi, Epidermis; sb, sebaceous gland; hf, hair follicle.
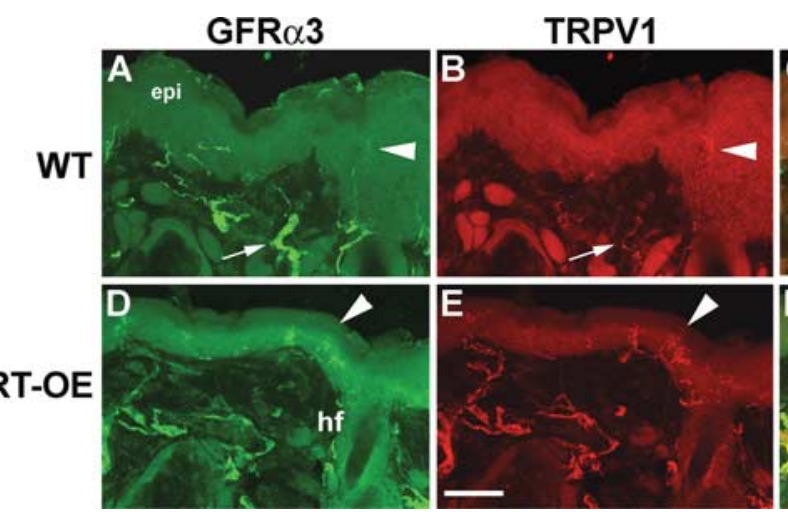

Figure 5. Artemin increases the intensity of TRPV1 expression in GFR $\alpha 3$ epidermal afferents. High-magnification view of GFR $\alpha 3$ (green; $\boldsymbol{A}, \boldsymbol{D})$ and TRPV1 (red; $\boldsymbol{B}, \boldsymbol{E})$ labeling in whisker pad epidermis of adult WT $(\boldsymbol{A}-\boldsymbol{C})$ and ART-OE $(\boldsymbol{D}-\boldsymbol{F})$ mice. In WT skin, few dermal (arrows) and epidermal (arrowheads) GFR $\alpha 3$-positive fibers express TRPV1. In contrast, ART-OE skin has many TRPV1-positive fibers that appear to sprout in the epidermal layer $(\boldsymbol{E}, \boldsymbol{F})$. Scale bar (in $\boldsymbol{E}$ ), $40 \mu \mathrm{m}$. epi, Epidermis; hf, hair follicle.

ine TRPV1 activity, we used calcium imaging to compare the response of sensory neurons cultured from WT and ART-OE animals to the TRPV1 agonist capsaicin (Fig. 8). DRG neurons cultured for $18-24 \mathrm{~h}$ were exposed briefly ( $2 \mathrm{~s}$ ) to $1 \mu \mathrm{M}$ capsaicin. Ratiometric imaging using fura-2 dye showed capsaicin elicited calcium responses in significantly more ART-OE DRG neurons ( $66 \pm 6 \% ; n=5$ mice; 50 cells) than WT DRG neurons ( $46 \pm 2 \%$; $n=5$ mice; 26 cells; $p<0.020$ ) (Fig. $8 A$ ). The magnitude of the capsaicin-evoked calcium transient was also increased in ART-OE neurons $(1.24 \pm 0.1 \Delta \mathrm{F})$ relative to that in WT DRG neurons $(0.84 \pm 0.08 \Delta \mathrm{F})(p<0.002)$. As a control to test the specificity of this change, responses to $100 \mu \mathrm{M}$ ATP, a ligand that activates $\mathrm{P} 2 \mathrm{X} 3$ and $\mathrm{P} 2 \mathrm{Y}$ receptors in nociceptors and also activates calcium, was added to the cultures (Fig. $8 B$ ). No difference in calcium response was measured between DRG neurons from ART-OE (53\%; $0.43 \pm 0.05 \Delta \mathrm{F})$ and WT $(51 \% ; 0.45 \pm 0.04 \Delta \mathrm{F})$ animals, thus suggesting that skin-derived artemin modulates capsaicin sensitivity in a TRPV1-specific manner.

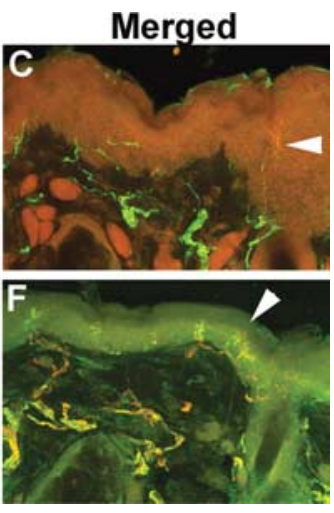

Artemin overexpression increases the behavioral response to thermal stimuli Based on our gene expression and physiological analysis, we performed behavioral measures of ART-OE mice to test for changes in sensitivity to mechanical and thermal stimuli. Von Frey filament testing of footpad skin showed no change in mechanical thresholds in ART-OE mice (WT, $5.27 \pm 0.33 \mathrm{mN}$ vs ART-OE, $5.14 \pm 0.37$ $\mathrm{mN}$ ), consistent with the ex vivo analysis of afferent properties. In contrast, withdrawal response times after exposure of footpads to radiant heat measured using a Hargreaves' apparatus were shorter. Animals were acclimated to the testing apparatus, and a focused radiant heat source was applied to glabrous skin of the hindfoot. Repeated measures of eight WT and eight ART-OE mice showed faster withdrawal in ART-OE mice $(6.33 \pm 0.27 \mathrm{~s}$; $p=0.004)$ compared with WT mice $(8.05 \pm 0.46 \mathrm{~s})$. These data support an intrinsic role for artemin in regulating sensitivity to noxious heating of the skin.

Similar to TRPV1, transcript levels of TRPA1 were also elevated in ART-OE ganglia and TRPA1 expression overlapped with GFR $\alpha 3$ expression. Because TRPA1 may contribute to sensing of cold (Story et al., 2003; Bandell et al., 2004), we tested whether ART-OE mice were more responsive to cold stimuli. Response to cold was tested by tail immersion in a bath set at either $0^{\circ} \mathrm{C}$ or $-15^{\circ} \mathrm{C}$ using two sets of 10 $\mathrm{WT}$ and 10 ART-OE mice (40 mice total). ART-OE mice exhibited lower thresholds at the $0^{\circ} \mathrm{C}$ bath temperature (WT, $10.64 \pm$ $1.67 \mathrm{~s}$; ART-OE, $5.15 \pm 1.42 \mathrm{~s} ; n=10 ; p=$ $0.010)$ and at the $-15^{\circ} \mathrm{C}$ bath temperature (WT, $15.09 \pm 2.78 \mathrm{~s}$; ART-OE, $5.22 \pm$ $1.03 \mathrm{~s} ; n=10 ; p=0.002)$. Artemin overexpression in the skin can therefore modulate cutaneous sensitivity to both heat and cold.

\section{Discussion}

We found that transgene-driven overexpression of artemin in skin keratinocytes enhanced developmental survival and functional properties of a unique subpopulation of sensory neurons that are GFR $\alpha 3$, TRPV1, and TRPA1 positive. The in vivo survival action of artemin shown in this study is consistent with studies in which increased survival of sensory, sympathetic, and enteric neurons cultured with artemin were observed. For sensory neurons, the greatest survival effect occurred in cultures derived from postnatal ganglia in which survival rates of up to $72 \%$ were measured (Baudet et al., 2000). Therefore, it was unexpected that E14.5 mouse embryos that lack artemin had normal projections of GFR $\alpha 3$-positive afferents. In addition, adult DRGs from $\mathrm{ART}^{-1-}$ mice were normal in size and showed no change in overall density of IB4- and CGRP-positive neurons (Baloh et al., 1998; Enomoto et al., 2001; Honma et al., 2002). This arteminindependent survival in GFR $\alpha 3$-positive neurons may reflect 
overlapping GFL dependencies (i.e., GDNF or neurturin may support survival of these neurons through binding of GFR $\alpha 3$, GFR $\alpha 1$, or GFR $\alpha 2$, because these receptors can be expressed in these neurons) (Baudet et al., 2000). NGF signaling through TrkA, which is expressed in GFR $\alpha 3$ neurons (Orozco et al., 2001), may also have promoted survival. However, actual counts of sensory neurons were not reported, so it remains a possibility that a small loss in sensory neurons and defects in projection pattern did occur in animals lacking artemin.

In newborn mice, neuronal expression of GFR $\alpha 3$ mRNA is robust from the day of birth, being localized to $20-34 \%$ of smalland intermediate-sized neurons (Naveilhan et al., 1998; Baudet et al., 2000; Honma et al., 2002). In adult mice, 19$20 \%$ of DRG neurons express GFR $\alpha 3$ (Orozco et al., 2001; this study), supporting a role for artemin in adult systems and during development. In this study, overexpression of artemin in the skin caused a $20.5 \%$ increase in neuron number in the DRGs of adult mice. Based on immunolabeling analysis, this increase likely reflects addition of small- to medium-diameter GFR $\alpha 3$ positive neurons that project to dermal and epidermal compartments of skin. GFR $\alpha 3$-positive nerve bundles appeared in upper dermal layers, and small-diameter fibers from these bundles penetrated through several layers of the epidermis. In WT skin, TRPV1 channel protein was only detected at low levels in few GFR $\alpha 3$-positive fibers. In contrast, nearly all GFR $\alpha 3$-positive fibers in ART-OE skin displayed high-intensity TRPV1 labeling. The increase in GFR $\alpha 3 /$ TRPV1-afferent colabeling likely reflects enhanced expression of TRPV1 protein and is consistent with elevation of TRPV1 mRNA and somal hypertrophy of TRPV1positive neurons. An even greater increase in TRPA1 mRNA occurred in ART-OE ganglia, suggesting artemin signaling also regulates TRPA1 expression. That many TRPA1-positive neurons were GFR $\alpha 3$ immunopositive further supports this possibility.

The expression of TRPV 1 and TRPA1, in virtually all GFR $\alpha 3$ neurons, suggests artemin supports nociceptor neurons that respond to various noxious stimuli such as heat, cold, capsaicin, and pungent compounds. We analyzed the effect of artemin on functional properties of C-fiber neurons in adult ART-OE DRG using an intact skin, nerve, DRG, and spinal cord preparation. Relative to WT animals, C-fibers of ART-OE mice showed no difference in mechanical threshold but did exhibit a significant reduction in heat threshold and increased firing frequencies in response to a heat ramp applied to the skin. This change in $\mathrm{C}$-fiber heat response may underlie, in part, the increased behavioral response to noxious heat demonstrated by ART-OE animals. These findings also suggest the level of skin-derived artemin modulates thermal sensation. The artemin-mediated increase in TRPV1 channel expression in GFR $\alpha 3$-positive afferents is consistent with this role. The artemin-related change in C-fiber sensitivity is similar to effects of NGF on cultured rat DRG neurons (Galoyan et al., 2003). Growing neurons in NGF medium enhanced inward current in response to high heat $\left(>43^{\circ} \mathrm{C}\right)$, although the threshold temperature was unchanged. Similarly, C-fiber afferents in mice that overexpress NGF in skin (NGF-OE mice) exhibited increased firing frequencies but had unchanged
GFR $\alpha 3$
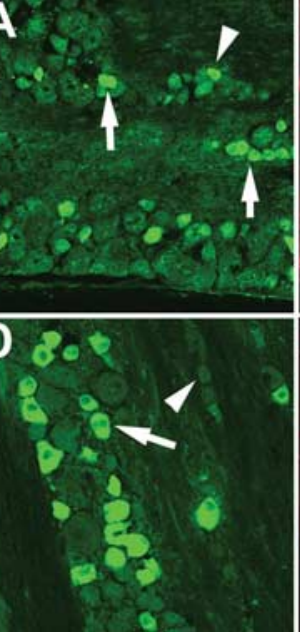

TRPA1
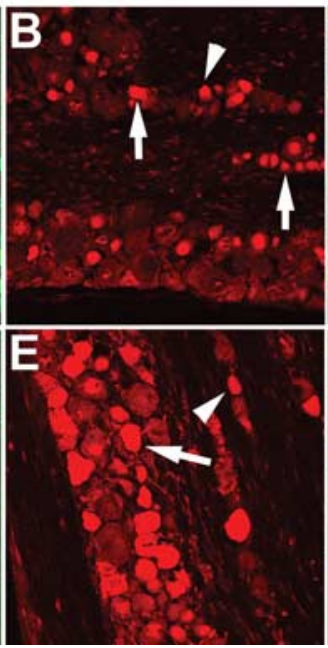

Merged
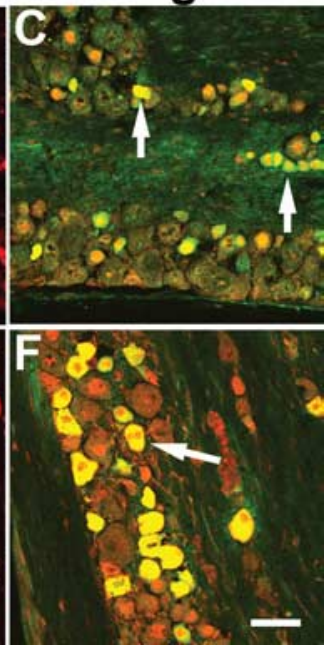

Figure 6. GFR $\alpha 3$-positive afferents express the TRPA1 channel. $A$, GFR $\alpha 3$ immunolabeling (green) of WT (A-C) and ART-OE $(\boldsymbol{D}-\boldsymbol{F})$ DRGs show GFR $\alpha 3$-labeled neurons exhibit TRPA1 immunoreactivity (red). Complete overlap in labeling occurred in both WT and ART-OE ganglia. Similar overlap in GFR $\alpha 3$ and TRPA1 labeling was found in the DRG. Scale bar (in $\boldsymbol{F}$ ), $70 \mu \mathrm{m}$.
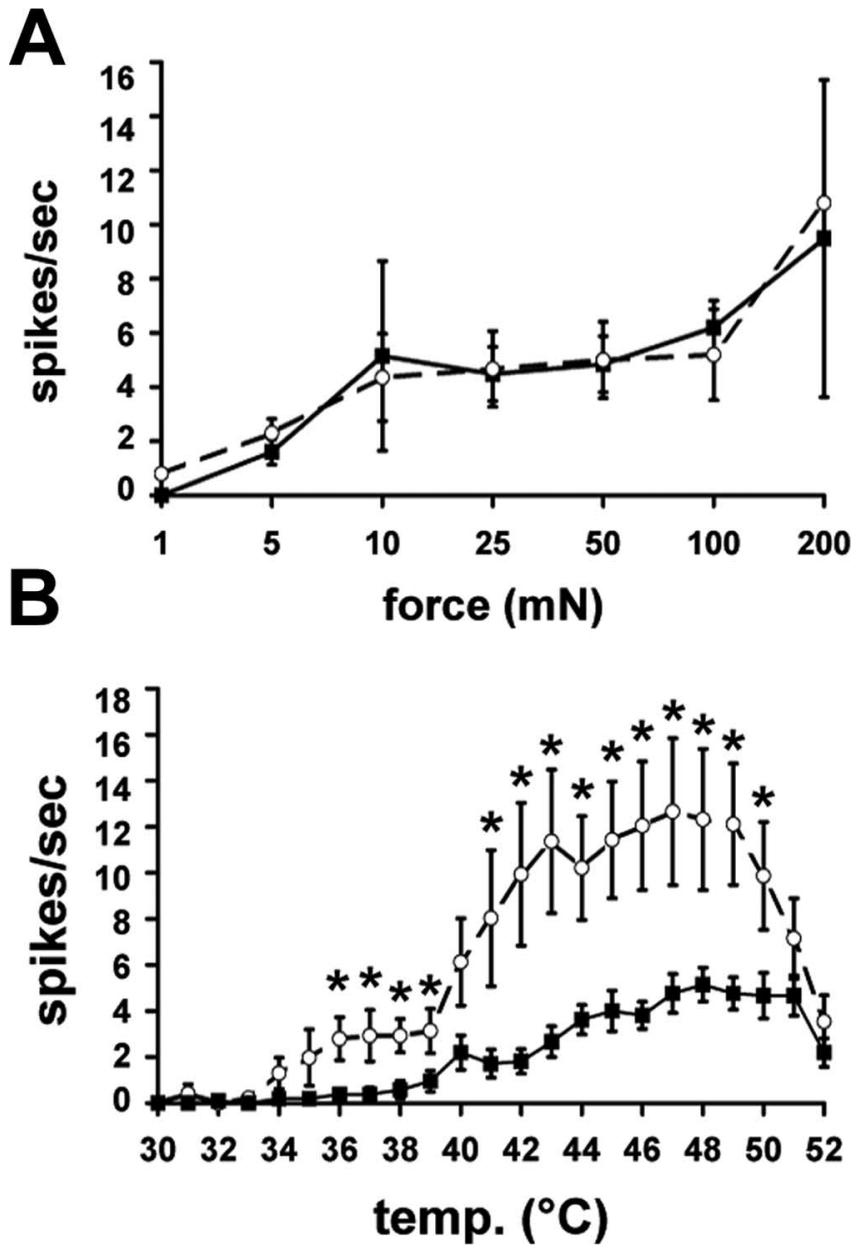

Figure 7. Increased levels of artemin sensitizes cutaneous C-fibers to thermal stimuli. An ex vivo preparation of the skin, nerve, DRG, and spinal cord was used to compare thermal and mechanical properties of cutaneous C-fibers in WT and ART-OE mice. ART-0E afferents had no change in mechanical response properties $(\boldsymbol{A})$ but did exhibit significantly lower heat thresholds (see Results) and significantly higher firing rates over a range of noxious temperatures (temp.; $\boldsymbol{B}$ ). 

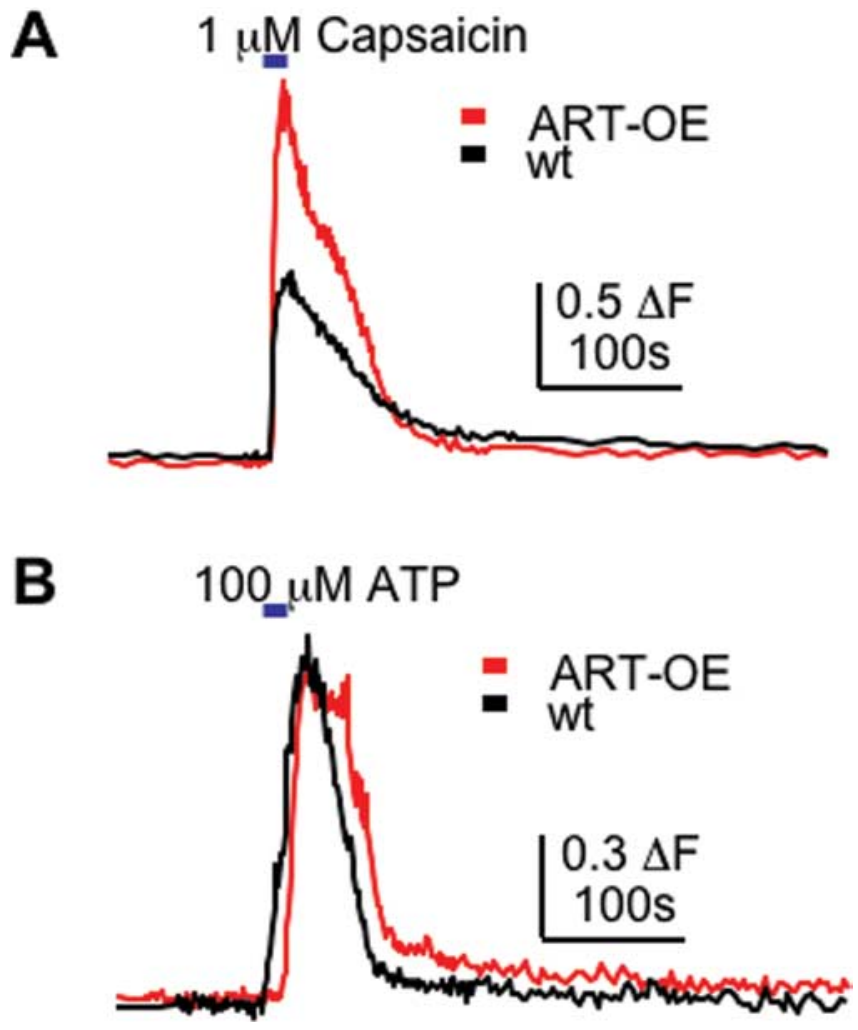

Figure 8. Artemin enhances the response to capsaicin in cultured sensory neurons. Calcium transients elicited by brief exposure to $1 \mu \mathrm{m}$ capsaicin were measured in DRG neurons acutely isolated from adult WT and ART-0E mice. $A$, Representative calcium response obtained from WT and $\mathrm{ART}-\mathrm{OE}$ neurons measured by fura- 2 ratiometric imaging. Capsaicin caused an increase in intracellular calcium concentration in significantly more ART-OE neurons compared with WT neurons (see Results), and these neurons had larger responses to capsaicin compared with WT neurons $(p<0.002)$. $B$, Response to $100 \mu \mathrm{M}$ ATP was not affected in ART-OE neurons, suggesting that the enhanced capsaicin response in ART-OE neurons results from changes in TRPV1 rather than an overall increase in excitability.

heat thresholds (Stucky et al., 1999). In addition, unlike ART-OE animals, NGF-OE mice and mice that overexpress GDNF in skin (GDNF-OE) mice showed no increase in TRPV1 mRNA in DRG neurons (Zwick et al., 2003; Molliver et al., 2005).

To test whether artemin overexpression affects chemical response properties, WT and ART-OE DRG neurons were exposed to the TRPV1 agonist capsaicin. Calcium imaging showed more ART-OE DRG neurons responded to capsaicin and that these neurons, on average, exhibited stronger responses. The enhanced TRPV1 activation could occur because of modification of channel properties caused by receptor tyrosine kinase signaling induced by artemin binding (Wang and Woolf, 2005). Increased TRPV1 expression in GFR $\alpha 3$-positive neurons is also likely to underlie, in part, the enhanced response to capsaicin. That artemin increases TRPV1 expression is also significant because artemin mRNA expression rises dramatically after inflammation of the skin (Malin et al., 2006) and TRPV1 contributes to inflammatory pain (Caterina et al., 2000; Davis et al., 2000). Artemin signaling may therefore have a key role in modulating TRPV1 expression and, in turn, afferent sensitivity in response to painful inflammatory stimuli.

Previous studies of GDNF-OE mice showed IB4-positive C-fibers had increased mechanosensitivity that correlated with enhanced ASIC2 levels (Albers et al., 2006). In the DRG of ART-OE mice, ASIC mRNAs were significantly decreased in a sex-specific manner. Male mice had less ASIC2a, whereas female mice had reduced levels of ASIC1, ASIC2a, ASIC2b, and ASIC3. The basis for this sex specificity is unclear, as is the effect of decreased ASIC expression on sensory coding. One might expect ART-OE mice to be less mechanically sensitive, but no change in mechanosensitivity was measured by behavioral or ex vivo criteria. A likely explanation is that GDNF and artemin act on different populations of sensory neurons, and these populations have different mechanisms for regulating mechanical sensitivity. Additional single-cell studies will be required to determine the relationship between ASIC expression, artemin level, and modulation of mechanical signaling.

An important finding was the enhanced expression of TRPA1 mRNA in GFR $\alpha 3$-positive neurons of ART-OE mice. This increase, coupled with the enhanced behavioral sensitivity to cold, supports a role for TRPA1 in noxious cold detection (Story et al., 2003; Bandell et al., 2004) and suggests TRPA1-positive cutaneous afferents contribute to in vivo perception of cold temperature. However, whether TRPA1 directly signals noxious cold has been debated. Studies support a direct activation of TRPA1 by cold in heterologous and DRG culture systems (Story et al., 2003; Bandell et al., 2004) and a role in cold hyperalgesia (Katsura et al., 2006). Two recent reports of TRPA1 knock-out models, in which only a portion of the TRPA 1 channel is translated, gave conflicting results. Bautista et al. (2006) reported normal cold responses, whereas Kwan et al. (2006) reported impaired cold responses. TRPA1 therefore appears to have a complex role in cold sensation that may be dependent on mouse strain or method of testing. Even so, given the TRPA1 increase in GFR $\alpha 3$ neurons and the behavioral response data, it is reasonable to conclude that the enhanced withdrawal response of ART-OE mice to noxious cold is attributable in part to activation of TRPA1.

Neuropathic pain can become a chronic condition resistant to current pharmacological therapies. To understand how this condition becomes intractable, interest has focused on the role of growth factors such as NGF and artemin in the development and maintenance of pain conditions. The effect of artemin on pain after nerve injury in the rat has been investigated using spinal nerve ligation (SNL) injury models (Gardell et al., 2003; Bolon et al., 2004). Gardell and colleagues (Malan et al., 2000; Gardell et al., 2003) reported that subcutaneous injection of artemin (1 mg/ $\mathrm{kg}) 3 \mathrm{~d}$ after nerve ligation significantly reduced tactile and thermal hypersensitivity within $24 \mathrm{~h}$ and normalized changes in spinal dynorphin levels, a pronociceptive agonist of the $\kappa$-opioid receptor that typically rises after SNL. In another study of artemin and nociception after SNL, no change occurred in mechanical allodynia after artemin was administered intraperitoneally (5 $\mathrm{mg} / \mathrm{kg}$ ) or by intrathecal infusion (Bolon et al., 2004). Thus, the effects of artemin on pain signaling appear dependent on the dose and route of delivery. In the present study, because artemin is produced in the skin during development and in the adult transgenic, it is hard to say how artemin-induced changes in cutaneous afferents might affect nociceptive signaling. However, what does seem likely is that the modest increase in artemin-responsive afferents in the skin coupled with the enhanced level of TRP channel expression contributed to the increased thermal sensitivity exhibited by the ART-OE mice. Thus, artemin-responsive sensory afferents likely have an important role in nociceptive processing after injury.

\section{References}

Airaksinen MS, Saarma M (2002) The GDNF family: signaling, biological functions and therapeutic value. Nat Rev Neurosci 3:383-394.

Albers KM, Wright DE, Davis BM (1994) Overexpression of nerve growth 
factor in epidermis of transgenic mice causes hypertrophy of the peripheral nervous system. J Neurosci 14:1422-1432.

Albers KM, Perrone TN, Goodness TP, Jones ME, Green MA, Davis BM (1996) Cutaneous overexpression of NT-3 increases sensory and sympathetic neuron number and enhances touch dome and hair follicle innervation. J Cell Biol 134:487-497.

Albers KM, Woodbury CJ, Ritter AM, Davis BM, Koerber HR (2006) Glial cell-line-derived neurotrophic factor expression in skin alters the mechanical sensitivity of cutaneous nociceptors. J Neurosci 26:2981-2990.

Baloh RH, Tansey MG, Lampe PA, Fahrner TJ, Enomoto H, Simburger KS, Leitner ML, Araki T, Johnson Jr EM, Milbrandt J (1998) Artemin, a novel member of the GDNF ligand family, supports peripheral and central neurons and signals through the GFRalpha3-RET receptor complex. Neuron 21:1291-1302.

Baloh RH, Enomoto H, Johnson Jr EM, Milbrandt J (2000) The GDNF family ligands and receptors-implications for neural development. Curr Opin Neurobiol 10:103-110.

Bandell M, Story GM, Hwang SW, Viswanath V, Eid SR, Petrus MJ, Earley TJ, Patapoutian A (2004) Noxious cold ion channel TRPA1 is activated by pungent compounds and bradykinin. Neuron 41:849-857.

Baudet C, Mikaels A, Westphal H, Johansen J, Johansen TE, Ernfors P (2000) Positive and negative interactions of GDNF, NTN and ART in developing sensory neuron subpopulations, and their collaboration with neurotrophins. Development 127:4335-4344.

Bautista DM, Movahed P, Hinman A, Axelsson HE, Sterner O, Hogestatt ED, Julius D, Jordt SE, Zygmunt PM (2005) Pungent products from garlic activate the sensory ion channel TRPAl. Proc Natl Acad Sci USA 102:12248-12252.

Bautista DM, Jordt SE, Nikai T, Tsuruda PR, Read AJ, Poblete J, Yamoah EN, Basbaum AI, Julius D (2006) TRPA1 mediates the inflammatory actions of environmental irritants and proalgesic agents. Cell 124:1269-1282.

Bennett DL, Michael GJ, Ramachandran N, Munson JB, Averill S, Yan Q, McMahon SB, Priestley JV (1998) A distinct subgroup of small DRG cells express GDNF receptor components and GDNF is protective for these neurons after nerve injury. J Neurosci 18:3059-3072.

Benson CJ, Xie J, Wemmie JA, Price MP, Henss JM, Welsh MJ, Snyder PM (2002) Heteromultimers of DEG/ENaC subunits form $\mathrm{H}^{+}$-gated channels in mouse sensory neurons. Proc Natl Acad Sci USA 99:2338-2343.

Bolon B, Jing S, Asuncion F, Scully S, Pisegna M, Van GY, Hu Z, Yu YB, Min H, Wild K, Rosenfeld RD, Tarpley J, Carnahan J, Duryea D, Hill D, Kaufman S, Yan XQ, Juan T, Christensen K, McCabe J, et al. (2004) The candidate neuroprotective agent artemin induces autonomic neural dysplasia without preventing peripheral nerve dysfunction. Toxicol Pathol 32:275-294.

Carmillo P, Dago L, Day ES, Worley DS, Rossomando A, Walus L, Orozco O, Buckley C, Miller S, Tse A, Cate RL, Rosenblad C, Sah DW, Gronborg M, Whitty A (2005) Glial cell line-derived neurotrophic factor (GDNF) receptor $\alpha$-1 (GFR $\alpha-1)$ is highly selective for GDNF versus artemin. Biochemistry 44:2545-2554.

Caterina MJ, Leffler A, Malmberg AB, Martin WJ, Trafton J, Petersen-Zeitz KR, Koltzenburg M, Basbaum AI, Julius D (2000) Impaired nociception and pain sensation in mice lacking the capsaicin receptor. Science 288:306-313.

Corey DP, Garcia-Anoveros J, Holt JR, Kwan KY, Lin SY, Vollrath MA, Amalfitano A, Cheung EL, Derfler BH, Duggan A, Geleoc GS, Gray PA, Hoffman MP, Rehm HL, Tamasauskas D, Zhang DS (2004) TRPA1 is a candidate for the mechanosensitive transduction channel of vertebrate hair cells. Nature 432:723-730.

Davis JB, Gray J, Gunthorpe MJ, Hatcher JP, Davey PT, Overend P, Harries MH, Latcham J, Clapham C, Atkinson K, Hughes SA, Rance K, Grau E, Harper AJ, Pugh PL, Rogers DC, Bingham S, Randall A, Sheardown SA (2000) Vanilloid receptor-1 is essential for inflammatory thermal hyperalgesia. Nature 405:183-187.

Encinas M, Tansey MG, Tsui-Pierchala BA, Comella JX, Milbrandt J, Johnson Jr EM (2001) c-Src is required for glial cell line-derived neurotrophic factor (GDNF) family ligand-mediated neuronal survival via a phosphatidylinositol-3 kinase (PI-3K)-dependent pathway. J Neurosci 21:1464-1472.

Enomoto H, Heuckeroth RO, Golden JP, Johnson EM, Milbrandt J (2000) Development of cranial parasympathetic ganglia requires sequential actions of GDNF and neurturin. Development 127:4877-4889.

Enomoto H, Crawford PA, Gorodinsky A, Heuckeroth RO, Johnson Jr EM,
Milbrandt J (2001) RET signaling is essential for migration, axonal growth and axon guidance of developing sympathetic neurons. Development 128:3963-3974.

Figueiredo HF, Davis BM, Albers KM (2001) Skin-derived nerve growth factor blocks programmed cell death in the trigeminal ganglia but does not enhance neuron proliferation. Mech Dev 109:205-214.

Galoyan SM, Petruska JC, Mendell LM (2003) Mechanisms of sensitization of the response of single dorsal root ganglion cells from adult rat to noxious heat. Eur J Neurosci 18:535-541.

Gardell LR, Wang R, Ehrenfels C, Ossipov MH, Rossomando AJ, Miller S, Buckley C, Cai AK, Tse A, Foley SF, Gong B, Walus L, Carmillo P, Worley D, Huang C, Engber T, Pepinsky B, Cate RL, Vanderah TW, Lai J, et al. (2003) Multiple actions of systemic artemin in experimental neuropathy. Nat Med 9:1383-1389.

Hargreaves K, Dubner R, Brown F, Flores C, Joris J (1988) A new and sensitive method for measuring thermal nociception in cutaneous hyperalgesia. Pain 32:77-88.

Harrison SM, Davis BM, Nishimura M, Albers KM, Jones ME, Phillips HS (2004) Rescue of NGF-deficient mice I: transgenic expression of NGF in skin rescues mice lacking endogenous NGF. Brain Res Mol Brain Res 122:116-125.

Heuckeroth RO, Enomoto H, Grider JR, Golden JP, Hanke JA, Jackman A, Molliver DC, Bardgett ME, Snider WD, Johnson Jr EM, Milbrandt J (1999) Gene targeting reveals a critical role for neurturin in the development and maintenance of enteric, sensory, and parasympathetic neurons. Neuron 22:253-263.

Honma Y, Araki T, Gianino S, Bruce A, Heuckeroth R, Johnson E, Milbrandt $J$ (2002) Artemin is a vascular-derived neurotropic factor for developing sympathetic neurons. Neuron 35:267-282.

Jones III RC, Xu L, Gebhart GF (2005) The mechanosensitivity of mouse colon afferent fibers and their sensitization by inflammatory mediators require transient receptor potential vanilloid 1 and acid-sensing ion channel 3. J Neurosci 25:10981-10989.

Katsura H, Obata K, Mizushima T, Yamanaka H, Kobayashi K, Dai Y, Fukuoka T, Tokunaga A, Sakagami M, Noguchi K (2006) Antisense knockdown of TRPA1, but not TRPM8, alleviates cold hyperalgesia after spinal nerve ligation in rats. Exp Neurol 200:112-123.

Koerber HR, Woodbury CJ (2002) Comprehensive phenotyping of sensory neurons using an ex vivo somatosensory system. Physiol Behav 77:589-594.

Krimm RF, Miller KK, Kitzman PH, Davis BM, Albers KM (2001) Epithelial overexpression of BDNF or NT4 disrupts targeting of taste neurons that innervate the anterior tongue. Dev Biol 232:508-521.

Krishtal O (2003) The ASICs: signaling molecules? Modulators? Trends Neurosci 26:477-483.

Kwan KY, Allchorne AJ, Vollrath MA, Christensen AP, Zhang DS, Woolf CJ, Corey DP (2006) TRPA1 contributes to cold, mechanical, and chemical nociception but is not essential for hair-cell transduction. Neuron 50:277-289.

Leitner ML, Wang LH, Osborne PA, Golden JP, Milbrandt J, Johnson Jr EM (2005) Expression and function of GDNF family ligands and receptors in the carotid body. Exp Neurol 191:S68-79.

Lindahl M, Timmusk T, Rossi J, Saarma M, Airaksinen MS (2000) Expression and alternative splicing of mouse Gfra4 suggest roles in endocrine cell development. Mol Cell Neurosci 15:522-533.

Lindfors PH, Voikar V, Rossi J, Airaksinen MS (2006) Deficient nonpeptidergic epidermis innervation and reduced inflammatory pain in glial cell line-derived neurotrophic factor family receptor alpha2 knock-out mice. J Neurosci 26:1953-1960.

Lucini C, Maruccio L, Tafuri S, Bevaqua M, Staiano N, Castaldo L (2005) GDNF family ligand immunoreactivity in the gut of teleostean fish. Anat Embryol (Berl) 210:265-274.

Malan TP, Ossipov MH, Gardell LR, Ibrahim M, Bian D, Lai J, Porreca F (2000) Extraterritorial neuropathic pain correlates with multisegmental elevation of spinal dynorphin in nerve-injured rats. Pain 86:185-194.

Malin SA, Molliver DC, Koerber HR, Cornuet PK, Frye R, Albers KM, Davis BM (2006) Glial cell line-derived neurotrophic factor family members sensitize nociceptors in vitro and produce thermal hyperalgesia in vivo. J Neurosci 26:8588-8599.

McKemy DD, Neuhausser WM, Julius D (2002) Identification of a cold receptor reveals a general role for TRP channels in thermosensation. Nature 416:52-58. 
Mogil JS, Adhikari SM (1999) Hot and cold nociception are genetically correlated. J Neurosci 19:1-5.

Molliver DC, Wright DE, Leitner ML, Parsadanian AS, Doster K, Wen D, Yan Q, Snider WD (1997) IB4-binding DRG neurons switch from NGF to GDNF dependence in early postnatal life. Neuron 19:849-861.

Molliver DC, Cook SP, Carlsten JA, Wright DE, McCleskey EW (2002) ATP and UTP excite sensory neurons and induce CREB phosphorylation through the metabotropic receptor, P2Y2. Eur J Neurosci 16:1850-1860.

Molliver DC, Lindsay J, Albers KM, Davis BM (2005) Overexpression of NGF or GDNF alters transcriptional plasticity evoked by inflammation. Pain 113:277-284.

Naveilhan P, Baudet C, Mikaels A, Shen L, Westphal H, Ernfors P (1998) Expression and regulation of GFRalpha3, a glial cell line-derived neurotrophic factor family receptor. Proc Natl Acad Sci USA 95:1295-1300.

Orozco OE, Walus L, Sah DW, Pepinsky RB, Sanicola M (2001) GFRalpha3 is expressed predominantly in nociceptive sensory neurons. Eur J Neurosci 13:2177-2182.

Peier AM, Moqrich A, Hergarden AC, Reeve AJ, Andersson DA, Story GM, Earley TJ, Dragoni I, McIntyre P, Bevan S, Patapoutian A (2002) A TRP channel that senses cold stimuli and menthol. Cell 108:705-715.

Price MP, McIlwrath SL, Xie J, Cheng C, Qiao J, Tarr DE, Sluka KA, Brennan TJ, Lewin GR, Welsh MJ (2001) The DRASIC cation channel contributes to the detection of cutaneous touch and acid stimuli in mice. Neuron 32:1071-1083.

Quartu M, Serra MP, Manca A, Mascia F, Follesa P, Del Fiacco M (2005) Neurturin, persephin, and artemin in the human pre- and full-term newborn and adult hippocampus and fascia dentata. Brain Res 1041:157-166.

Reid G (2005) ThermoTRP channels and cold sensing: what are they really up to? Pflügers Arch 451:250-263.

Ritter AM, Woodbury CJ, Albers K, Davis BM, Koerber HR (2000) Matu- ration of cutaneous sensory neurons from normal and NGFoverexpressing mice. J Neurophysiol 83:1722-1732.

Sariola H, Saarma M (2003) Novel functions and signalling pathways for GDNF. J Cell Sci 116:3855-3862.

Silverman JD, Kruger L (1988) Lectin and neuropeptide labeling of separate populations of dorsal root ganglion neurons and associated "nociceptor" thin axons in rat testis and cornea whole-mount preparations. Somatosens Res 5:259-267.

Story GM, Peier AM, Reeve AJ, Eid SR, Mosbacher J, Hricik TR, Earley TJ, Hergarden AC, Andersson DA, Hwang SW, McIntyre P, Jegla T, Bevan S, Patapoutian A (2003) ANKTM1, a TRP-like channel expressed in nociceptive neurons, is activated by cold temperatures. Cell 112:819-829.

Stucky CL, Koltzenburg M, Schneider M, Engle MG, Albers KM, Davis BM (1999) Overexpression of nerve growth factor in skin selectively affects the survival and functional properties of nociceptors. J Neurosci 19:8509-8516.

Stucky CL, Rossi J, Airaksinen MS, Lewin GR (2002) GFR alpha2/neurturin signalling regulates noxious heat transduction in isolectin B4-binding mouse sensory neurons. J Physiol (Lond) 545:43-50.

Wang H, Woolf CJ (2005) Pain TRPs. Neuron 46:9-12.

Woodbury CJ, Koerber HR (2003) Widespread projections from myelinated nociceptors throughout the substantia gelatinosa provide novel insights into neonatal hypersensitivity. J Neurosci 23:601-610.

Zwick M, Davis BM, Woodbury CJ, Burkett JN, Koerber HR, Simpson JF, Albers KM (2002) Glial cell line-derived neurotrophic factor is a survival factor for isolectin B4-positive, but not vanilloid receptor 1-positive, neurons in the mouse. J Neurosci 22:4057-4065.

Zwick M, Molliver DC, Lindsay J, Fairbanks CA, Sengoku T, Albers KM, Davis BM (2003) Transgenic mice possessing increased numbers of nociceptors do not exhibit increased behavioral sensitivity in models of inflammatory and neuropathic pain. Pain 106:491-500. 